Please cite as:

Murtagh, N., Lopes, P.N. \& Lyons, E. (2007) What makes a career barrier a barrier?

Industrial and Commercial Training. 39(6):332-339

\title{
What makes a career barrier a barrier?
}

\section{Abstract}

Purpose The purpose of this paper is to present research findings on the experience of career barriers by women who have changed career, and to suggest the practical implications of these findings for career management.

Design/Methodology/Approach An established, qualitative methodology, Interpretative Phenomenological Analysis, was used to explore participants' experiences. Semistructured interviews were conducted with 8 women who had changed careers and were analysed to identify the salient themes.

Findings Participants experienced career barriers, but their subjective experience did not necessarily match objectively defined barriers. One participant, for example, experienced redundancy not as a barrier to her career path but as an opportunity. It was only when situations or events threatened the self-concept that problems were experienced as barriers. These barriers were not insurmountable and participants used a number of strategies to overcome potential barriers.

Practical implications The findings suggest that career management or counselling should acknowledge and explore the client's subjective experience of career barriers. 
Strategies such as challenging or reframing potential barriers can be effective methods for helping clients to dismantle them.

Originality/Value This research points to the gap in career theory and research on the experience of barriers in adult careers. It presents evidence on the subjective nature of barriers and on strategies used to overcome them.

Keywords Career barriers, subjective experience, self-concept

Classification Research paper

\section{Introduction}

Most careers require the negotiation of many potential barriers. Society's structures impose constraints. Women, minority groups and working class people typically face more limitations in their careers than do White men from affluent backgrounds. There are other potential barriers too. Jobs require particular qualifications and experience and offer a variable range of pay and prospects. Employers often seek a particular 'type' of applicant, who, they believe, will 'fit'. Redundancy can end a career path. Organisations thus can impose barriers which determine the course of careers, by controlling access to skills and opportunities (Thomas, 1989). The power of organisations to allow or deny access to opportunities and levels of pay still constitutes an overwhelming force in people's experience of careers. 
Classic career theories, such as those of Schein (1978), Holland (1973)) and Super (1957; 1990) acknowledged influences including socioeconomic class, parents and the economy but did not consider how these factors can affect career paths. These theories, commonly used in career counselling and coaching, see personality and environment types, career 'anchors' or life stages as the primary determinants of careers, but ignore the effect of barriers.

The only major career theory to have addressed barriers is Social Cognitive Career Theory (Lent, Brown \& Hackett, 1994). This theory considered a variety of possible constraints which can limit career choices, ranging from objective, contextual factors such as the economy or social class, to subjective, within-person influences, such as predispositions or self-efficacy. A critical point of this theory was that the subjective experience of constraints may not match objective views: for example, an individual may experience redundancy as an opportunity.

Most research on career barriers has looked prospectively at adolescents' expectations of future constraints. For example, Banks, Bates, Breakwell, Bynner, Emler, Jamieson, et al (1992) focused on teenagers' career intentions and concluded that their career aspirations aligned with their conception of what they were capable of, which was based in part on their class, race, gender and education. The Career Barriers Inventory (CBI; Swanson et al., 1996), the most relevant measurement instrument, assesses anticipated constraints. However, the lived experience of barriers may not be the same as their anticipation. What 
teenagers expect to be a problem in their future careers may feel very different when, as adults, they experience it. Few studies have used the experiences of working adults. Very little is known about the barriers faced by adults as they move through their working lives, how such barriers affect career paths and how individuals deal with them. This leaves practitioners of career counselling or coaching without adequate theory or research for potentially important aspects of an individual's experience. The research presented here addresses that gap.

Most existing research on barriers has taken a quantitative approach, which required the researcher to specify career barriers (e.g. the CBI). However, individuals' subjective experience of barriers may not match objectively defined barriers. Although gender, race and class can limit an individual's career, these constraints may not be relevant for the individual, may not be experienced as limitations, or may not be the only barriers experienced.

For this reason, we chose a qualitative approach to explore participants' experiences in depth. Using Interpretative Phenomenological Analysis (IPA), an established methodology described in Smith and Osborn (2003), we focused on people's subjective experience and how they make sense of it. In brief, IPA uses participants' accounts of their experience as the data, which the researcher then interprets by iteratively looking for themes. These themes are then clustered into master themes that reflect the salient aspects of the participants' experience, remain true to their accounts and contribute to understanding in the field of research. 
Because women's experience of career differs from men's (Gallos, 1989; Marshall, 1989) and because much existing career theory and research assumes a normative career path that is more relevant to men than women (Cohen, Duberley \& Mallon, 2004; Fitzgerald $\&$ Harmon, 2001), we chose women participants. The experiences of a less-studied group are of interest in their own right and can provide additional insights into the moreresearched groups.

\section{Method}

We investigated the experience of career barriers in 8 women between the ages of 25 and 50, who had changed career within the last 3 years. Career change was defined as a change which involved different roles, responsibilities and field of expertise. The participants were recruited through the first author's social networks.

Table 1 summarises the participants' demographic details.

Take in Table 1

Table 1 Summary of Participants' Demographics

\begin{tabular}{|c|c|}
\hline Demographic & Range \\
\hline Age & $27-48$ \\
\hline Education & Degree level: 7 GCSEs: 1 \\
\hline Class Indicator & Homeowners:7 Council flat: 1 \\
\hline Ethnicity & White: $7 \quad$ Black Caribbean: 1 \\
\hline Location & Based in the UK for at least 15 years: 7 \\
\hline
\end{tabular}


\begin{tabular}{|l|l|}
\hline Mothers with dependent children & 5
\end{tabular}

All participants were living in the south-east of England. Five participants were mothers, with between 1 and 4 children ranging in age from 6 to early 20s. The participant who was council-housed was educated to GCSE-level and described her ethnicity as White.

Table 2 summarises the participants' old and new careers. The names of participants and organisations have been changed to preserve anonymity.

Take in Table 2

Table 2 Participants' Old and New Careers

\begin{tabular}{|l|l|l|l|}
\hline $\begin{array}{l}\text { Participant } \\
\text { Number }\end{array}$ & Pseudonym & Previous Career & Current/New Career \\
\hline 1 & Clare & $\begin{array}{l}\text { Caterer - part-time } \\
\text { employed; part-time own } \\
\text { small business }\end{array}$ & $\begin{array}{l}\text { Senior personal } \\
\text { administrator (PA) }\end{array}$ \\
\hline 2 & Brenda & Biochemist & $\begin{array}{l}\text { Alternative therapy } \\
\text { practitioner and trainer }\end{array}$ \\
\hline 3 & Gayle & Retail manager & E-marketing consultant \\
\hline 4 & Anne & Caterer & Academic researcher \\
\hline 5 & Fran & Stable hand & Coach driver \\
\hline 6 & Joan & $\begin{array}{l}\text { Senior retail buyer / } \\
\text { change manager }\end{array}$ & Secondary teacher \\
\hline 7 & Helen & Civil servant & Academic researcher \\
\hline 8 & Diane & Geoscientist/manager & Occupational psychologist \\
\hline
\end{tabular}

Two separate semi-structured interviews were conducted by the first author with each participant. Open questions were asked on: job history, triggers for change, identity change, emotions around the change, learning in the new career, and the influence of other people. The interviews were recorded and transcribed verbatim. 
Analysis was carried out in accordance with IPA recommendations (Smith \& Osborn, 2003): starting with one participant, themes were noted while reading and rereading the text. After initial coding into themes, higher level or master themes were identified, with continuous reference to the data, to enable clustering of the themes.

\section{Analysis}

From the analysis of the participants' accounts of career change, master themes relating to career barriers emerged. Working from the barriers each participant experienced, we focussed on how barriers were experienced. In order to bring the subjective experiences into sharper relief, the experience of problems which were not experienced as barriers was then explored. This contrast between problems construed as barriers, and career problems which were not experienced as barriers, was especially informative.

The stories referred to the experience of a number of career barriers, including:

- Structural barriers, including lack of money and lack of access to higher education

- Psychological hurdles, including low self-expectations

- Social norms and expectations, in particular low expectations for women's careers

- Women's primary responsibility for childcare

- Conflict between requirements of job and of childcare. 
In the subjective experience of career barriers, four major themes were (1) acceptance, (2) frustration, (3) 'reaching my potential' and (4) 'a need to prove myself'.

The participants appeared to accept some of the barriers they perceived, although with a sense of frustration, in some cases acute, in others nagging:

"I think that a lot of the time, when I was doing those part-time em poorlypaid jobs, I think I was very frustrated. (...)[1,2] I don't think I was really myself because a lot of the time I was frustrated and quite depressed really about the fact that I was being forced into doing something by circumstances.” (Clare)

In articulating their frustration, some participants referred to a need or a desire to realise their potential, a feeling that they could be doing more:

“I just sort of felt like I wasn't, I wasn't reaching my own potential, if that's the right way to put it. I just felt that I really could have and should have been in a, doing an awful lot more with the qualifications that I had." (Gayle)

For several participants, this desire related to an expressed need to prove themselves, to themselves or to others:

"I think there was a big sort of thing about I'll show, people I'm never ever going to see again, haven't seen for years and years and years, I'll show 
them. Those people at school who thought I was crap, I'll show them (...)

I'll show them I'm not a stupid person they thought I was." (Helen)

Other participants expressed unmet needs for achievement, for intellectual challenge, for autonomy in their job. For two participants, it was about doing something they had a passion for:

"it'll always be driving. I just love it. Queen of the road" (Fran)

"It's passion. (...) It's something I truly believe in." (Brenda, referring to her new career).

So psychological needs sat alongside practical reasons for career change, and for all participants in this study, their psychological needs were a salient part of their accounts of career change. These needs appeared to coalesce around identity needs, around how the participants saw themselves or wanted to see themselves: as competent and capable of achieving, as intellectually able, as doing something they truly enjoyed.

Not all experiences of potential barriers were problematic, however. The participants described problems during their career change, including age, availability of opportunities and redundancy, which they did not construe as insurmountable barriers. For one participant, the poor pay and prospects in her job seemed to spur her on to action: "earning the amount of money that I was on, you know, my manager at the time as well had been with Acme for 15 years and was earning about $£ 18,000$ and I thought, well ok, I have another 11 years to reach the same 
sort an extra $£ 4000$ a year (...) and I’m not going to stand here for 11 years and wait for that $£ 4000$, I’m going to go out and I'm going to get it, you know, and that was like a determination almost." (Gayle).

What could have been construed as a barrier instead seemed to serve as a trigger for change.

In another example, a participant experienced her redundancy as "an opportunity" to change career:

"if it hadn't been that I'd been offered the financial lifeline [the redundancy payment], I would never have been able to do it.” (Joan)

Joan saw the redundancy fitting in with what she wanted to achieve in her life. In a similar way, she did not see having children as a barrier to her career, but as an experience that changed her priorities. Her career then had to fit in with her new priorities. Asked if there were other constraints on what she could choose, Joan responded:

"Em [pause] not really, no. The only constraints were those that I placed on myself in terms of, you know, not wanting a job like, (...) I didn't want something that was going to involve a lot of travel, overnight trips, that sort of thing. (...) So only, they weren't really constraints then because they were things that almost, you know, personal values that I would have put into the pot. (...) Don't want to work long hours, don't want to work abroad, don't want all of these things, so it's not a constraint that was 
imposed on me. They're constraints that or values I had that I wanted a job to be able to accommodate. (...) I wasn't going to look for anything that wasn't going to allow me, my domestic situation to be as I would want it to be, really."

In Joan's story, it seems as though her career with a major retailer - where she had worked for many years and was in a management position - became the barrier to how she wanted to live her life. Her sense-making of her experience shows clearly how the subjective interpretation of barriers may not align with objective expectation.

So what made the difference between what was construed as a barrier and what was not? The critical differentiating factor appeared to be whether the potential barrier prevented the individual from achieving wants, needs or values of personal salience. Joan was clear about her values and her aims, so neither redundancy nor childcare were experienced as barriers. For the other participants too, they expressed frustration at barriers that prevented them from achieving their potential and realising their desired self. It was the involvement of the self-concept - how they thought about themselves or wanted to see themselves - that appeared to differentiate potential barriers from situations actually construed as barriers.

Even where barriers were experienced, the participants found ways to overcome them. We have seen above how Gayle used poor pay as a trigger and a motivator to change 
career. For some participants, a challenge to their assumptions led them to transform what had been a barrier:

"I never actually, you know, I never really thought about it [doing a PhD] as an option for me. I thought really, that's not for me, and then was actually we were all sitting round at the end of a class or something and [the lecturer] said to me "are you doing a $\mathrm{PhD}$ too?" I said no, and she said “well, why aren't you? You can do one too. You're just as capable as soand-so, and so-and-so.” And it was only then that, you know, having somebody say "you're actually capable of doing this", that made me actually even think about it.” (Helen).

For others, taking a different perspective dismantled the barrier. Gayle had initially felt that doing further study would have been a step back:

"the first thing that flits through your mind is like taking a step back rather than moving forward."

but then she spoke to a friend:

"she basically said to me “( ...) it's not only about studying, it's about personal growth" (...) I thought (...) if I see it as a retraining as well, and that's the way I approached it then (...) It's not taking a step back. It's retraining and I invested in that.” (Gayle) 
Reframing the potential barrier in several cases resulted in overcoming it. It is interesting to note that, in these accounts, it is someone else who challenges the participant or prompts her to take a new perspective on the barrier.

\section{Discussion and Practical Implications}

Our findings have practical implications for career development, particularly for one-toone career counselling or coaching. Firstly, these interviews remind us of the reality of structural barriers in working lives. Acknowledging and understanding the difficulties that clients experience in their careers is important for counsellors and coaches, in order to establish empathy and rapport. This is also an important issue for diversity management.

While career counsellors should acknowledge the existence of structural barriers, they should also explore their clients' subjective experience. As the data here suggested, subjective experience may not align with objective expectations.

Exploring barriers can reveal much about the client's values and psychological needs, and, of particular importance, can indicate who the client wants to be. This can then help in decisions about future careers. For example, the client who appears frustrated about lack of promotion may need recognition. He or she may see promotion as a proxy for recognition within his/her work environment. By exploring the meaning for the client of the barrier of lack of promotion, the underlying psychological needs and desired self may 
come to be understood. Solutions can then be explored which satisfy the identity needs, instead of focusing on the barrier.

The strategies for overcoming barriers that the participants reported using also suggest practical applications. Challenging the client's perceived barriers may allow barriers to be confronted and dismantled. For example, asking "why do you believe you could not get the qualification?" may reveal long-held self-beliefs that are no longer relevant, as in Helen's view about doing a PhD. As we have seen above, a challenge by others can lead individuals to reframe their potential barriers.

Explicitly seeking to reframe barriers is a further strategy. For example, asking the client to think of how someone else would describe their situation, or how they themselves will describe it in 10 years, can prompt a reframing of barriers and suggest ways to overcome them.

In summary, this study suggested that barriers are part of people's experience of careers, but that it is the subjective experience of constraints that matters most. Barriers tend to be perceived as frustrating psychological needs, particularly those relating to the selfconcept. Our findings suggest several useful strategies for career management and counselling: exploring subjective barriers and who the client wants to become, challenging perceived barriers and looking for ways to reframe them may help career counselling clients along their desired career path.

\section{Notes}


[1] (...) is used to indicate text omitted for the sake of clarity.

[2] Quotations are verbatim, including hesitations, repetitions, etc. in order to present the data accurately.

\section{Reference List}

Banks, M., Bates, I., Breakwell, G., Bynner, J., Emler, N., Jamieson, L. et al. (1992). Careers and Identities. Buckingham: Open University Press.

Cohen, L., Duberley, J., \& Mallon, M. (2004). Social constructionism in the study of career: accessing the parts that other approaches cannot reach. Journal of Vocational Behavior, 64, 407-422.

Fitzgerald, L. F. \& Harmon, L. W. (2001). Women's career development: a postmodern update. In F.T.L.Leong \& A. Barak (Eds.), Contemporary models in vocational psychology: a volume in honor of Samuel Osipow (pp. 207-230). Mahweh, NJ: Lawrence Erlbaum Associates.

Gallos, J. V. (1989). Exploring women's development: implications for career theory, practice and research. In M.B.Arthur, D. T. Hall, \& B. S. Lawrence (Eds.), Handbook of career theory (pp. 110-132). Cambridge: Cambridge University Press.

Holland, J. L. (1973). Making vocational choices: a theory of careers. Englewood Cliffs, NJ: Prentice Hall.

Lent, R. W., Brown, S. D., \& Hackett, G. (1994). Toward a unifying social cognitive theory of career and academic interest, choice and performance. Journal of Vocational Behavior, 45, 79-122.

Marshall, J. (1989). Re-visioning career concepts: a feminist invitation. In M.B.Arthur, D. T. Hall, \& B. S. Lawrence (Eds.), Handbook of career theory (pp. 275-291). Cambridge: Cambridge University Press.

Schein, E. H. (1978). Career dynamics: matching individuals and organisations. Reading, MA: Addison-Wesley.

Smith, J. A. \& Osborn, M. (2003). Interpretative Phenomenological Analysis. In J.A.Smith (Ed.), Qualitative psychology: a practical guide to research methods (pp. 51-80). London: Sage.

Super, D. E. (1957). The psychology of careers. New York: Harper and Row. 
Super, D. E. (1990). A life-span, life-space approach to career development. In D.Brown, L. Brooks, \& and Associates (Eds.), Career choice and development (pp. 197261). San Francisco, CA: Jossey-Bass.

Swanson, J. L., Daniels, K. K., \& Tokar, D. M. (1996). Assessing perceptions of careerrelated barriers: the Career Barriers Inventory. Journal of Career Assessment, 4, 219-244. 